\title{
Urinoma formation following laparoscopic oophorectomy
}

\author{
Ryan Hillier-Smith
}

Royal Free Hospital, London, UK

\section{Correspondence to} Dr Ryan Hillier-Smith, ryan.hillier-smith@nhs.net

Accepted 1 August 2014
CrossMark

To cite: Hillier-Smith $R$. BMJ Case Rep Published online: [please include Day Month Year] doi:10.1136/ bcr-2014-205975

\section{DESCRIPTION}

A 38-year-old woman underwent a laparoscopic oophorectomy using a harmonic scalpel to remove a $8 \times 10 \mathrm{~cm}$ cyst. Four days after the procedure she presented to A\&E with sharp increasing lower abdominal pain associated with fever, reduced appetite, constipation, dysuria and increased urinary frequency. Investigations revealed a raised $\mathrm{C}$ reactive protein and mildly elevated creatinine. She was discharged for A\&E with antibiotics for a presumed pelvic infection.

She represented 3 weeks later with severe abdominal pain and persistent constipation. She was admitted and treated with laxatives. Five days into her admission she continued to complain of abdominal pain which was now radiating to her

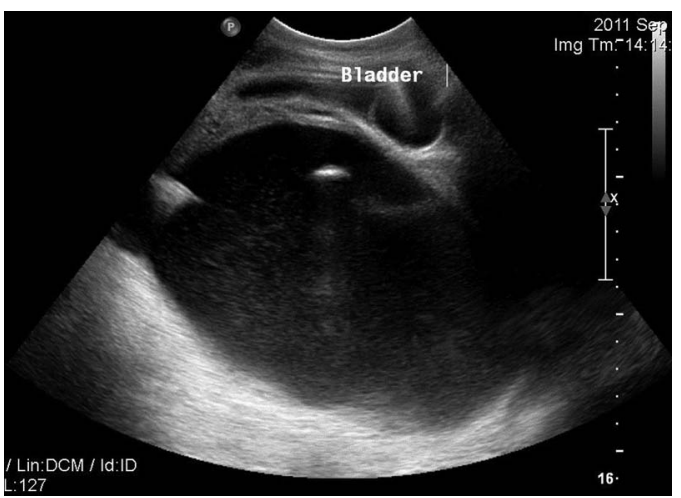

Figure 1 Pelvic ultrasound showing $16 \mathrm{~cm} \times 9.3 \mathrm{~cm} \times 13 \mathrm{~cm}$ cystic structure. back. She was passing dark, concentrated urine and her abdomen was distended. At this point, a pelvic ultrasound scan was performed which showed a $16 \mathrm{~cm} \times 9 \mathrm{~cm} \times 13 \mathrm{~cm}$ multiloculated cyst in her left adnexa (figure 1).

The following morning she underwent an emergency laparotomy which revealed a thick-walled, fluid-filled structure posterior to the uterus. Needle aspiration of the cyst revealed urine. A urologist was called to theatre and a cystoscopy was performed. This demonstrated a leak from the lower third of the ureter. A stent was placed across the damaged segment of the ureter and the patient made a full recovery.

\section{Learning points}

- The increasing use of laparoscopic surgery has led to an increased incidence of ureteral injuries, especially in gynaecological procedures.

- A potential ureteral injury should be considered as a differential diagnosis when patients present with abdominal pain following laparoscopic procedures.

Competing interests None.

Patient consent Obtained.

Provenance and peer review Not commissioned; externally peer reviewed.

Copyright 2014 BMJ Publishing Group. All rights reserved. For permission to reuse any of this content visit http://group.bmi.com/group/rights-licensing/permissions.

BMJ Case Report Fellows may re-use this article for personal use and teaching without any further permission.

Become a Fellow of BMJ Case Reports today and you can:

- Submit as many cases as you like

- Enjoy fast sympathetic peer review and rapid publication of accepted articles

- Access all the published articles

- Re-use any of the published material for personal use and teaching without further permission

For information on Institutional Fellowships contact consortiasales@bmjgroup.com

Visit casereports.bmj.com for more articles like this and to become a Fellow 